\title{
Strengthening Borders, Managing Centres: Reception Conditions and Provisions of Services to Asylum Seekers in Croatia
}

DOI: https://doi.org/10.11567/met.34.3.1 UDK: 314.15:343.62]:341.43(4:497.5)

Izvorni znanstveni rad Primljeno: 13.02.2019.

Kristina Pandek Prihvaćeno: 13.05.2019.

Sesvete

kpandek022@gmail.com

Drago Župarić-lljić

Department of Sociology, Faculty of Humanities and Social Sciences, University of Zagreb

dzuparic@ffzg.hr

\section{SUMMARY}

This article analyses the impact that the Common European Asylum System may have on asylum seekers residing in reception centres within Croatia, as well as more recent challenges related to increased asylum seekers' numbers and difficulties they might pose for the reception standards and provision of services. We posit that a degree of variation occurs in the treatment of asylum seekers throughout reception centres in the EU. The analysis sheds light on the Croatian asylum reception system, one that had been legally obligated to fully harmonise its policies with the EU acquis during the EU accession process. Based on the field research in the form of semi-structured interviews among the stakeholders and asylum seekers at the Reception Centre for Asylum Seekers Kutina in 2016, the findings will demonstrate that although Croatia has fully adapted its regulations to the Reception Conditions Directive, there are still issues regarding the minimum standards of quality of reception, service provision and future integration of protection claimants. The authors contend that gaps and insufficiencies in the reception conditions and standards are directly decreasing asylum seekers' future prospects by affecting their chances of integration into Croatian society and resulting in significant secondary movement of these migrants to other EU countries. Even more, in the aftermath of the Balkan corridor, the present challenges of increased numbers of asylum applicants are calling for the planning of new and proper reception facilities, which is difficult to accomplish in the context of overtly securitised asylum and migration policies.

KEY WORDS: asylum seekers, Common European Asylum System (CEAS), reception, Croatia, Balkan Corridor, refugees, integration 


\section{INTRODUCTION}

During 2015 and 2016, the European Union (EU) encountered an increased arrival of more than a million forced migrants and has employed solutions for their immediate reception, or in the case of Croatia, for the organisation of their swift transit to Western Europe (Šelo Šabić, 2017), which was a reaction similar to that of other neighbouring countries, at least before the tactics of setting razor-wires and army on borders took over. ${ }^{1}$ The situation, oftentimes coined as the so-called "European migration/refugee crisis" (European Commission, 2016; Rogelj, 2017) of unprecedented scale, has shifted the position of Western Balkan countries from refugee producing (back in the 1990s) and traditional emigration countries, to transit territories for a vast majority of forced migrants on their way to Western Europe (cf. Sardelić, 2017; Pastore, 2019). A drift to securitisation practices that have taken place following the EU-Turkey deal of March 2016 subsequently led to the closure of the Balkan corridor, and to strengthening the borders while trying to manage asylum and irregular migration in a more securitised and militarised manner. In parallel, practices of criminalisation of migrants and citizens' activism and solidarity towards them resulted in a situation of political contestation of human rights and humanitarian concerns (Bužinkić and Hameršak, 2018). In 2017 and 2018, some borderline communities in Serbia and Bosnia and Herzegovina became reception hubs for thousands of irregular migrants stranded along this part of the Balkan route.

Even in the earlier times, but especially since 2015, achieving solidarity among all Member States has been paramount because adequate tackling of migration issues has been an important test of interconnectivity for envisaging and implementing the EU migration and asylum policy. This policy seems to lack in coherence, reciprocity and a long-term vision. According to the Common European Asylum System (CEAS), the thresholds of which were founded almost 20 years ago and the fundaments of which are nowadays heavily disputed, reception centres for asylum seekers within the EU Member States are required under the EU Reception Conditions Directive $^{2}$ for the purpose of hosting and accommodating protection (asy-

1 This article is based on the major research paper submitted by the first author to the Faculty of Graduate and Postdoctoral Affairs in partial fulfilment of the requirements for the degree of Masters of Arts in European, Russian and Eurasian Studies, at Carleton University in Ottawa, Canada (cf. Pandek, 2017).

2 Directive 2013/33/EU of the European Parliament and of the Council of 26 June 2013 laying down standards for the reception of applicants for international protection, Official Journal of the European Union L 180/96, http://eur-lex.europa.eu/legalcontent/EN/TXT/?uri=celex\%3A32013L0033. 
lum) seekers. In general, the idea of "first reception" implies hosting new arrivals, which is followed by providing accommodation to people who have already entered the asylum procedure. Later, upon recognition of their protection status, we speak of the housing of refugees, be they asylum grantees or persons under subsidiary protection. Therefore, reception facilities are commonly designed to provide a temporary home to asylum seekers until their claim has been processed. Depending on the type of facility, they may also provide other necessities including food, basic health care and cash allowance.

The focus of this paper will be on the implementation of the Reception Conditions Directive since it serves as a base for establishing common standards of living conditions for asylum applicants within reception centres across the EU. We argue that, since the EU encompasses 28 sovereign countries with different disproportionate pressures on their asylum systems, the EU institutions are facing difficulties in creating a well-functioning, sustainable and harmonised policy, which is being revealed in national contexts such as Croatia. This paper will discuss not only the extent of policy harmonisation achieved by the CEAS through the case study of the Kutina reception centre in Croatia based on the field research conducted in 2016, but also some of the current challenges concerning reception conditions within the context of increased asylum seeker recorded in 2017 and 2018. We argue that it is important to look at such centres and analyse the extent to which Member States are following the EU regulations because asylum seekers, as migrants who are still in procedure for status recognition, might be(come) vulnerable and disempowered by policy inconsistencies.

We highlight the main differences in policy implementation that continue to prevail within reception centres throughout the EU because it offers us important insights into the levels and modes by which harmonisation has been accomplished in the Croatian asylum system. The main questions we address are: to what extent do the reception conditions in Croatia fulfil the requirements outlined in the Receptions Conditions Directive and what can we learn from the case of Croatia about the EU asylum policies and the implementation of norms and (minimum) standards? Our findings are based on the desk research of reception conditions and EU directives, European Commission Progress Reports for Croatia and local NGO reports, as well as on field research including interviews with stakeholders and with asylum seekers, conducted in 2016. Additionally, we briefly discuss the current trends and policies regarding the newly established reception 
facilities intended as transit reception centres in the borderline territories on the very edge of Schengen, in order to depict the current situation relating to the forthcoming asylum reception challenges in Croatia.

We argue that the Croatian legislation closely follows the Reception Conditions Directive, even though the minimum standards required by the CEAS provide for policy flexibility, which enables Member States to take more control over the type of policies being implemented within their country. As such, Croatian asylum norms are in line with the EU legislation, but the state has the ability to define its own standards (cf. Lalić Novak, 2016). However, the disinterest of the Croatian government in developing better reception conditions and better prospects for integration as well as the fact that many asylum seekers leave the asylum system and status recognition procedure by venturing irregularly further west oftentimes result in the cancelation of procedures for reluctant asylum claimants, and even in secondary movements of recognised refugees, as pointed out by the previous research of Valenta, Zuparic-Iljic and Vidovic (2015). We find this rather problematic, not only in terms of the sole responsibility of national institutions but also in terms of an inherent inconsistency of the overall Dublin system and of the CEAS, which we scrutinise in the following section.

\section{REVIEW OF THE CEAS AND RECEPTION STANDARDS FOR ASYLUM SEEKERS}

The objective of the CEAS is to create common policies throughout the EU and ensure that the human rights of asylum seekers and refugees are being met. Current literature, including scholars such as Pirjola (2009) and Velluti (2014), shows that there is often a tension between the two conflicting priorities; human rights considerations and issues of state sovereignty and border control. While universal commitments call for providing assistance to those in need, the language of nationalism has often led to notions of "otherness", creating a legal, societal and political division between nationals and asylum seekers. Although the struggle between these two objectives can be directly reflected in the policies encompassing the CEAS, an additional third factor, the role of the EU and the processes of harmonising its policies with the national legislative and institutional frame (known as the Europeanisation process, cf. Lalić Novak and Padjen, 2009; Baričević, 2013), should also be considered because it acts as a liaison between these ideas, creating the final policy approach towards migration management. 
The securitisation of asylum issues has been well researched by various scholars in the global, European and local context (cf. Squire, 2009; Triandafyllidou and Dimitriadi, 2014; Pozniak and Petrović, 2014). It is posited that securitisation goes against the logic of Europeanisation, which was initially based on the principles of acceptance, solidarity and "accommodating otherness". It is not only problematic in view of restricting the human rights of asylum seekers, but it also hampers the prospect for further successful EU integration. Progress in such regard is hindered because the laws on asylum are seen as a paradox, which is characterised by the struggle between the objectives of EU institutions and individual Member States' interests when it comes to migration legislation and practices of managing and controlling migration (Chetail, 2016).

Although Member States are often accused of the lack of policy harmonisation throughout the EU and are characterised as being in favour of a more restrictive migration policy, scholars such as Lindstrom (2005) and Costello and Hanox (2015) contend that the complexity of EU governance could also hinder policy harmonisation and the protection of human and refugee rights. Lalić Novak and Padjen (2009: 75) discuss the degrees to which EU Member States would harmonise their protection standards with the EU acquis, concluding that "(i)t is apparent that minimum standards are an insufficient incentive for the proper harmonisation of national asylum systems, leaving too high a level of discretion to the Member States regarding the transposition of the legal acquis into national systems. The Europeanisation of the asylum policy has not been inspired by humanitarian considerations, but by policies of the Member States to discourage and prevent asylum seekers from accessing state territories on the one hand, and to promptly and efficiently process asylum applications on the other." With a lack of concrete certainty, this initial problematic tension in the CEAS has actually led to some visible gaps between the policy and implementation at national levels (Schweitzer, Consterdine and Collyer, 2018).

In relation to the treatment of asylum seekers, it is questionable whether the CEAS can sufficiently charge the states with providing adequate and common treatment throughout the EU. There has been much criticism of the present system from various international organisations such as the UNHCR and the European Council on Refugees and Exiles (ECRE, 2016) pointing to a problem that continued differences among EU members in their approaches to reception may severely impact the lives of asylum 
seekers and have negative repercussions on the prospects of the quality of protection, i.e. future integration of beneficiaries (cf. van Moortel, 2007; Pollet, Soupios-David and Teffera, 2013). This is visible when comparing any two Member States with significant differences in asylum policies. For example, one of the most advanced Member States in hosting refugees - Sweden, provides two types of accommodation to asylum seekers, the same as Croatia. A person can either arrange their own accommodation if s/he possesses the means to do so, or the Swedish Migration Agency arranges accommodation for them. ${ }^{3}$ In case of the latter, the accommodation often entails an apartment shared with other asylum seekers where there is much more privacy and independence comparative to a reception centre. At the moment there is no such option in the Croatian case because all the asylum seekers who cannot arrange for themselves are accommodated in collective reception centres located in Zagreb and in Kutina. These reception differences are not surprising given the fact that Sweden is a considerably wealthier country with a better reception infrastructure, more efficient governance, stronger political will for humanitarian assistance and a long tradition of hosting refugees, including those who arrived during "the long summer of migration" (Kasparek and Speer, 2015).

The specific experience of the increased, some say massive, arrival of forced migrants in 2015 and 2016 seemed to find Europe unprepared for taking a unified and efficient approach to admitting, redistributing and hosting people with shared responsibility and solidarity. Thus, as pointed by Bačić Selanec (2015: 73) "Union in its centralised capacity failed to activate an efficient legal framework to respond to a crisis of the present magnitude, thus creating a perfect ground for individual Member States to become the main actors of crisis management, each invoking its own political particularities and national interests". Initial responses diverted from the politics of German Willkommenskultur to the politics of razor-wire fences and closed border in Hungary and some other central and South-eastern European countries (Macedonia, Slovenia). While the system of receiving asylum seekers and refugees according to relocation and resettlement quotas was obstructed by the Visegrad group countries, Croatia has taken a combination of humanitarian and securitisation stance and agreed to accept people by quotas, while reducing the possibilities for further transit after the closure of the Corridor (Mikac and Cesarec, 2017; Šelo Šabić, 2017).

3 See at: https://www.migrationsverket.se/English/Private-individuals/Protection-and-asylumin-Sweden/While-you-are-waiting-for-a-decision/Accommodation.html 
However, whether and how the Balkan corridor episode has influenced the reception conditions and standards for asylum seekers in Croatia seems quite an under-investigated topic, remaining an open question we partly address in the conclusion.

\section{NATIONAL CONTEXT AND CURRENT ASYLUM TRENDS}

It would be misleading to claim that asylum issues are a "new topic" to Croatian society given the fact that its members helped to and assisted almost a million displaced population on the Croatian territory during the wars in the Balkans back in 1990s, and given the fact that the first asylum claimant was registered in Croatia in 1997, even before the state enacted the first Asylum Act in 2004. The 2000s were marked by a smaller number of asylum seekers, mostly arriving from the conflict-torn areas of surrounding countries (Serbia, Kosovo, Macedonia) and only since 2010 have we started to note larger numbers of people from the Middle East and Africa, with the majority originating from Afghanistan, Iraq and Syria (Barberić, 2015). In 2011, the number of asylum seekers had increased from 290 in 2010 to 807 in the subsequent year. ${ }^{4}$ These numbers continued to rise in the following years prior to entering the EU, with 1193 requests in 2012 and 1089 in 2013. Comparing these statistics to neighbouring countries in the region, Croatia received higher numbers than Bosnia and Herzegovina and Slovenia, but drastically lower numbers than Serbia and Hungary. Within the span of 6 years (2009-2014), Croatia received a total of 3,830 requests, while Serbia registered more than 28 thousand of expressed intentions for asylum (BCHR, 2015: 19), and Hungary 72,2755. However, joining the EU actually decreased the numbers of asylum applicants to 453 in 2014, and the year 2015, seeing an increased arrival of Syrian refugees and other forced migrants to Europe, brought "only" 152 asylum claimants in Croatia, despite the fact that almost 660,000 people transited through the Croatian part of the Balkan corridor, heading in swift, controlled and organised transit to Germany before the corridor's closure in March 2016 (Šelo Šabić, 2017).

The number of granted statuses in Croatia has increased lately. From 2004, when the first Asylum Act was enacted, up to the beginning of 2019, among

$4 \quad$ All statistical data presented in this section were taken and adjusted from the official Republic of Croatia - the Ministry of the Interior (MoI) data: https://mup.gov.hr/statistika-228/228

5 Asylum and first-time asylum applicants by citizenship, age and sex - annual aggregated data (rounded), code [migr_asyappctza], Eurostat, 2019, http://appsso.eurostat.ec.europa.eu/nui/ show.do?dataset=migr_asyappctza\&lang=EN 
almost 10 thousand of overall requests, there were around 750 recognised statuses, with two thirds of them being granted in the last three years. ${ }^{6}$ We argue that this relatively small ratio is due to the fact that Croatia had gradually implemented the EU migration regulations, which ensured better legislative transparency during the process, let alone the fact that a high proportion of procedures were cancelled because the claimants had left the country before first-instance decisions were issued. That being said, there is still a significant difference in the number of statuses provided comparative to other European countries. Although this is especially evident in developed countries of Western and Northern Europe, the numbers equalise when compared with smaller countries in the Central European surroundings such as Slovenia or Slovakia. ${ }^{7}$

Initial responses to increased arrivals in 2015 and 2016 mainly entailed "emergency crisis management" that meant organised short-term reception in temporarily established camps, followed by swift organised transit to a next station in the Corridor, rather than employing and enabling longer-term facilities and protection status options (Mikac and Cesarec, 2017; Bužinkić and Hameršak, 2018). With a gradual closure of the Balkan corridor, the securitisation practices of the new right-centrist government replaced the humanitarian approach of the former government that existed in parallel with securitisation during the corridor phase. Even though the corridor ceased to exist, the Eastern Mediterranean and the Balkan route have persisted. Suddenly, thousands of once again 'irregularised' migrants became stranded, intercepted and forcibly returned under the Dublin III Regulation, readmission agreements and/or push-backs in the counterdirection as a form of counter-corridor (ECRE and AIDA, 2016; OXFAM, BCHR and MYLA, 2017). However, the processes of forced returns and collective expulsions from the borders have impeded access to a territory for many of the stranded migrants, denying them the basic right to apply for protection in the Balkans. ${ }^{8}$ Closing the corridor and thus stopping the transit resulted in a sharp increase and then a gradual decrease in the num-

${ }_{6}$ The latest statistics are to be found at: https://mup.gov.hr/UserDocsImages/statistika/2019/ Tra\%C5\%BEitelji\%20me\%C4\%91unarodne\%20za\%C5\%A1tite\%20u\%202019\%20godini/2904-statistika-trazitelji-1-3-2019.pdf

7 First instance decisions on asylum applications by type of decision - annual aggregated data, Eurostat, 2019, https://ec.europa.eu/eurostat/tgm/table.do?tab=table\&init=1\&language=en\&pc ode=tps00192\&plugin $=1$

8 Even before the Balkan corridor episode, Giuffré (2013: 110) argued that "(i)n situations of informal border controls and massive arrivals of migrants and refugees where monitoring is generally lacking, the implementation of a readmission agreement may contribute to hinder access of asylum seekers protection." 
bers of asylum seekers in Croatia from 2234 in 2016, to 1887 in 2017, and 1068 in 2018. At some points, regular reception centres in Croatia were full or almost full. At the same time, being at the forefront of Schengen meant the strengthening of the borders which resulted in almost a doubling of irregular crossings from 4496 in 2016 to 8207 in 2018, and in a doubling of registered cases of smuggling within the territory.

Lastly, in 2018, we saw two parallel processes of admission and accommodation of Syrian refugees who were transferred to Croatia via resettlement quotas, as well as protection seekers being admitted via the relocation mechanism. In July 2015, Croatia has agreed to accept up to 550 people in total, 150 resettled from third countries and 400 relocated from other EU Member States. By the end of 2018, Croatia had managed to transfer and admit, via resettlement, 152 Syrian refugees from Turkey and 81 persons meeting the requirements for international protection being relocated from Italy and Greece. ${ }^{9}$ These processes pose new challenges to the significantly centralised system of integration, whereby in local communities across the country where these persons are accommodated (i.e. housed), many needs of local stakeholders have to be met in in order for them to act properly and to host these newcomers efficiently (Giljević and Lalić Novak, 2018; Ajduković et al. 2019), which is an issue we will address again later.

\section{METHODOLOGY AND LIMITATIONS OF THIS RESEARCH}

In order to analyse the implementation of the EU Reception Conditions Directive in Croatia, first we briefly discuss some characteristics of the reception standards in facilities within the EU Member States, based on our desk-research. Here we focus on the provision of rights available to asylum seekers, including the material conditions of accommodation, accessibility and mobility, and social benefits. To develop a comprehensive understanding of the EU's role and influence within the process of Croatia's asylum laws and reception conditions, we will refer to EU documents as well as to the Croatian legislation and reports.

Secondly, based on field research, we discuss whether and how the minimum EU requirements outlined in the Directive incentivise the Croatian government to invest efforts in the reception and integration of asylum seekers. The research was conducted using the methods of direct observation and semi-structured interviews in the Reception Centre for Asylum

9 See: vlada.gov.hr/UserDocsImages/2016/Sjednice/2019/Velja\%C4\%8Da/143\%20sjednica\%20 VRH/143\%20-\%204.docx 
Seekers in Kutina, which was initially opened in 2011 for the purpose of accommodating families and vulnerable asylum seekers, with a capacity of 100 beds. Interviews were conducted with 18 respondents in the course of two months, in January and February 2016, in a form of individual and group interviews. Six interviews were conducted with representatives of institutions, NGOs and other experts. Ten asylum seekers in the Kutina centre participated in this research, while two interviews were carried out with beneficiaries of international protection in Zagreb.

Correspondence and interviews with stakeholders were conducted in Croatian, including a Croatian Red Cross representative, UNHCR representative (interview conducted in Zagreb), NGO representatives of the Centre for Peace Studies (CPS) and Jesuit Refugee Service (JRS) and one of the JRS volunteers, as well as with the then mayor of Kutina (in his office). With the approval of the stakeholder respondents, all interviews were recorded, except with the MoI. The only form of communication with the MoI was through sending written questions via emails to the Ministry's Asylum Department in Zagreb, as in-person interviews could not be scheduled due to policy regulations in place. Although not many difficulties were encountered during the research process, obtaining the permission to enter the reception centre required a month.

Asylum seekers residing in the reception centre in Kutina demonstrated a fair interest in participating in the research. One focus group interview was conducted in English, including six asylum seekers, with one of them helping to translate from the Kurdish language into English. Other four interviews with asylum seekers were conducted on an individual basis either in English or in French, and in one case in Croatian, because the asylum seeker concerned spoke it fairly, given the fact he was coming from one of the Balkan countries. Two more interviews were conducted in Zagreb, with two persons who had been living in Croatia for some time, and had already obtained their protection statuses. The interviews with them and with the asylum seekers in Kutina were not recorded due to privacy concerns, but notes were taken. All personal data from these interviews have been anonymised, meaning that their names, ages and nationalities are purposefully omitted from the citations. ${ }^{10} \mathrm{~A}$ thematic analysis of the

10 A group of our adult respondents in the focus group included one young couple with a child, and secondly, an extended family of a middle-aged couple with a few children, a younger couple and one elderly member. Both groups were coming from two Middle-East countries, with different linguistic, cultural and religious backgrounds. Individual interviews in the Kutina centre were conducted with a middle-aged male from a Balkan country, and with two younger 
transcribed interviews was conducted in accordance with the rules posited in Guest, MacQueen and Namey (2012), employing inductive coding and a descriptive analysis of data collected within the following extracted subthemes: Material reception conditions, Social benefits/services provided, Disempowered position and other barriers, Accessibility and mobility. We discuss these subthemes in further analysis.

We are aware that limitations of our research relate to a specific spatial, temporal and socio-political context in the midst of increased arrivals and transit of forced migrants through Croatia as part of the Balkan corridor. Thus, the specific focus of the stakeholders and humanitarian actors we spoke to was more oriented towards transit migration management, whereas the conditions of reception in the Kutina facility at that point seemed to be just a technical, but known challenge to them. Secondly, our findings do not stem from investigating other reception conditions, either within the permanent and regular facilities of the Reception Centre in Zagreb (the socalled "Hotel Porin") characterised by a higher number of humanitarian actors and activities, or the then temporary conditions within the Winter Reception and Transit Centre in Slavonski Brod, which has been described by other authors (cf. Hameršak and Pleše, 2017; Bužinkić and Hameršak, 2018). Our sample of respondents included those state, civil and humanitarian actors as well as asylum seekers present in the Reception Centre Kutina; thus, one must have in mind that these results could help us to illustrate and to understand only one part of the reception issues and perspectives in the Croatian asylum system. Hopefully, an acknowledgment of these limitations would help to design some future research which will include more participants and be able to overcome some of the obstacles we faced.

\section{RESEARCH RESULTS}

\subsection{The EU standards of reception and of social benefits for asylum seekers}

The overall policies regarding the CEAS are discussed under Chapter 24 of the EU acquis and only the minimum standards are imposed onto all the participating states. The CEAS comprises three directives: the Asylum

males from two Central African countries. Additional interviews in Zagreb with refugees with recognised statuses included two young males coming from one Central African and one Central Asian country. 
Procedure Directive that sets out rules for the process of claiming asylum; the Reception Conditions Directive that deals with the reception standards for asylum seekers for the duration of their claim; and the Qualification Directive that specifies the grounds for granting international protection. The Directives' requirements as a minimum also give Member States a possibility to have higher policy standards if they so desire. As such, by requiring solely the minimum standards, it is less likely for Member States to resist adequate policy implementation, and the European Commission deliberately makes them easier to implement in order to counteract their potential circumvention by Member States. The flexibility provided within the Directives provides Member States with the ability to choose how and to what extent certain provisions are being enforced. The common policy therefore allows for inconsistencies, which has led experts to question the actual purpose of the CEAS, especially in a situation of massive arrivals that urge for more immediate protection solutions (Bačić Selanec, 2015; Chetail, 2016).

The current Reception Conditions Directive that came into force on 21 July 2015 applies to all Member States except Ireland and Denmark and aims to provide common regulations and standards on the reception of third country nationals who are requesting international protection. ${ }^{11}$ The Directive's requirements include a wide variety of policies regarding adequate accommodation, language courses, financial support and health coverage. In addition to harmonising the asylum policy, a further underlying objective of the Directive was to serve as an instrument to limit the secondary movement of applicants that could be influenced by differences among reception conditions present in each country. Nonetheless, it has been criticised as a Directive which offers solely the minimum standards or reception policies with ambiguous directions (ECRE, 2016). As such, the given flexibility provides Member States with the ability to determine, within these guidelines, the approach to be taken when attending to asylum seekers, resulting in vast differences in CEAS policy implementation occurring throughout the EU.

The problematic flexibility in the Reception Conditions Directive had been purposely allowed by the EU institutions in order to accommodate the differences among Member State objectives. According to the Asylum Infor-

11 Directive 2013/33/EU of the European Parliament and of the Council of 26 June 2013 laying down standards for the reception of applicants for international protection, Official Journal of the European Union L 180/96, http://eur-lex.europa.eu/legalcontent/EN/ TXT/?uri=celex\%3A32013L0033. 
mation Database (AIDA), the regular procedure ${ }^{12}$ dictates that accommodation be made available to asylum seekers in all EU countries. This might include private housing managed by provincial or local governments or NGOs, reception centres or accommodation camps. Although the Reception Conditions Directive provides Member States with the flexibility to determine the most adequate type of accommodation, its requirements (Article 18) include that they must guarantee an adequate standard of living and should acknowledge concerns such as the situation of vulnerable persons, gender and age-specific differences. The general conclusion made by the AIDA is that in the regular procedure, "(m)aterial reception conditions are made available to asylum seekers in the regular procedure in all AIDA countries". ${ }^{13}$

Further on, the majority of Member States provide the right to free movement within the entire territory of their respective country, but the right to mobility can be limited for a number of reasons, including public interest or order, as well as the swift processing of applications. Although varying in amount, a monthly financial allowance is provided to asylum seekers in all of the Member States, its conditions being outlined within their legislation. This flexibility is provided to Member States who can legally, if they so desire, change the living standards of asylum seekers. Although there are differences in the standard of living within Member States and this should not be ignored, the EU provisions guarantee (at least in theory, at a normative level) that asylum seekers are not treated poorly because of a vague policy, explicitly highlighting what kind of living standards are required.

\subsection{Development of Asylum Policies in Croatia under the umbrella of the EU acquis}

Although there might be issues with the CEAS and its implementation throughout the EU, according to EU progress reports, Croatia has gradu-

12 There are different types of asylum recognition procedural stages such as: Regular Procedure, Dublin Procedure, Accelerated Procedure, Appeal, Subsequent Application. For the purposes of this article, only the implementation of the Regular Procedure will be analysed. For others see: www.asylumineurope.org/comparator/reception. There are different types of asylum recognition procedural stages such as: Regular Procedure, Dublin Procedure, Accelerated Procedure, Appeal, Subsequent Application. For the purposes of this article, only the implementation of the Regular Procedure will be analysed. For others see: www.asylumineurope.org/comparator/ reception.

13 Countries included in the AIDA project and database are 17 EU Member States plus Serbia, Switzerland and Turkey (https://www.asylumineurope.org/about-aida). 
ally and successfully incorporated the EU acquis into its national legislative and institutional frame (European Commission, 2005, 2010). Therefore, the country's engagement within the process is hard to question. The same cannot be said about exceeding the EU minimum standards in order to better reflect the needs of asylum seekers. As previously discussed, these minimum standards in general do not adequately cover the provisions such as integration, which gives Member States flexibility in the degree of their availability. Therefore, the principles of state sovereignty and presupposed national interests are additional drivers of such flexibility, which could act as facilitators for improving or degrading the standard of reception and integration policies in general, as indicated by some previous studies (Baričević, 2013; Lalić Novak, 2016). As such, the sole underlying interest in Croatia's implementation of the minimum policies is not necessarily accounted for by the direct benefit of asylum seekers, but, in fact, by the desire to adjust its laws and practices by following such regulations in order to fulfil the prerequisites for joining the EU (achieved) and Schengen (pending).

Although a type of asylum act had already been established at the time Croatia was recognised as a sovereign state, such legislation officially began to develop further in parallel with the EU accession process. ${ }^{14}$ The Stabilisation and Association Agreement signed in $2001^{15}$ established the first major dialogue between Croatia and the EU. In the subsequent years of EU policy harmonisation, the asylum laws continued to be closely incorporated within the process (Lalić Novak, 2016). With closer EU cooperation, legislation changes started originating directly from the EU requirements to successfully adopt the acquis, making Croatia eligible for membership. The UNHCR's national activities in Croatia during early 200s had generally focussed more on resolving the issues of minority refugee return and achieving durable solutions for the population displaced during the war in the 1990s (Barberić, 2015).

From 2005 until 2011, the EU published yearly progress reports highlighting the main achievements and issues related to Croatia's policy development in all sections of the acquis. Such progress reports demonstrated the

14 Under these circumstances, it is debatable whether Croatia's first official Asylum Act (introduced on 1 July 2004) would have developed in the same pace and direction without the EU's guidance and the potential benefits the membership has to offer.

15 Stabilization and Association Agreement between the European Communities and their Member States, of the one part, and the Republic of Croatia, of the other, Official Journal of the European Union L 26/3, 2005. 
EU's interest and initiative to closely monitor and supervise Croatia's development process. With each progress report, Croatia further aligned its legislation with EU requirements. Some of the examples include opening the reception centre in Kutina in 2006 and putting into place a new Asylum Act in 2008. This had led to the final 2010 report stating that, "(s)ignificant progress can be reported in the field of asylum. The Act amending the Asylum Act entered into force in July 2010, fully aligning Croatia's legislation with the acquis" (European Commission, 2010: 54).

Examining the issues highlighted in Croatia's progress reports, there is a notable lack of concern among the European institutions about the provision of services within the reception centre in Kutina. Although, according to EU documents, Croatia had fully aligned its asylum law at that point, as suggested by these progress reports, no significant reference was given to the treatment of asylum seekers within reception centres. The issue of such treatment was solely mentioned in regard to the Reception Centre for Foreigners (i.e. detention and deportation centre for irregular migrants) Ježevo, which was overcrowded in the period 2006-2009. Such a situation could have occurred due to the fact that Croatia had higher numbers of irregular border crossings back in that period. Nevertheless, the lack of concern about the provision of services within the reception centre for asylum seekers in Kutina could potentially be related to the low numbers of migrants requesting asylum at that time.

It was only in 2011 when the number of asylum seekers significantly increased in the years prior to joining the EU. As a consequence, an additional reception centre was opened in the "Hotel Porin" in Zagreb, in 2011, ready to accommodate single male asylum applicants, with a capacity of 600 beds. Regardless of an increased number of applicants, the number of statuses granted remained low, and the majority of procedures were cancelled due to secondary movements. In order to keep the number of refugees relatively low in Croatia, one could ask whether authorities have used this situation to their advantage, further discouraging asylum seekers from remaining within the country by allowing for the implementation of less desirable policies, ones inhibiting applicants' potential for successful integration into society. ${ }^{16}$ We contend that early integration policies (stemming from the provisions in the Reception Conditions Directive) are in this

16 For the current national integration framework and specific integration policies and easures please check: https://ec.europa.eu/migrant-integration/?action=media.download\&uuid=BEE1A875FBFF-C720-7C5AF97C4271ACB1 
case crucial in order to ensure that all of them have equal opportunities to adapt to an environment where they need to start a new life.

\subsection{Material conditions at the Reception Centre Kutina}

The reception centre in Kutina opened in June 2006, intended to host regular asylum seekers, with a capacity of 100 people (Barberić, 2015). The city of Kutina is a mid-populated industrial town of around 25,000 people, approximately $70 \mathrm{~km}$ from the capital city of Zagreb. The reception centre itself is located on the outskirts, some $2 \mathrm{~km}$ from the town, in a former traffic police building, adapted for accommodation. The facility temporary closed down in 2013 for being overcrowded and requiring reconstruction. It was reopened in June 2014 with the purpose of providing accommodation to vulnerable asylum seekers: families with children, persons with disabilities, victims of torture or other forms of psychological or physical violence, which is in line with the EU regulations requesting special treatment for this group of people.

At the time of our visit to the field, most of asylum seekers in Kutina originated from Afghanistan, Syria, Iraq and many of them were of Kurdish descent. During our visit, the centre had families residing on one floor and men on the other. ${ }^{17}$ The changed setup served as a temporary solution to tackle the increased numbers of migrants crossing the Croatian border. Due to the increased arrivals in September 2015, all asylum seekers residing in the reception centre Hotel Porin were transferred temporarily to Kutina to create the potentially needed space for incoming migrants who would stay there a few days and then be sent to neighbouring countries, i.e. Slovenia (MoI correspondence). At the beginning of 2016, this sort of mixed arrangement was still in place in Kutina, with 63 people living there, even though the process of returning asylum seekers to Hotel Porin was already underway. ${ }^{18}$

Aside from the "special circumstances" during the corridor phase, the

17 This mixed setting where vulnerable asylum seekers such as families and children were living with men was not that unusual for the centre. The Red Cross was convincing us that there were no problems with having such a mixed arrangement in place in Kutina as in the previous years, from 2006 up to 2011, the centre provided accommodation to all profiles of asylum seekers (Red Cross respondent).

18 The number of persons within the Kutina centre was relatively low, but as explained by the Red Cross, incoming migrants at that time were not staying in Croatia, but were in fact being transferred by trains to Slovenia, which some researchers of the Balkan corridor referred to as a unique form of detention - "mobile detention" (Hameršak and Pleše, 2018: 25). 
"regular procedures" in the Kutina centre were "quite ordinary". With an office located within the Kutina centre the MoI is responsible for receiving asylum requests but it also administers the centre and it is charged with ensuring that the basic conditions of life are being met for asylum seekers. Non-state, humanitarian, civil actors are also involved within the asylum process and complement state activities. In addition to the MoI, the Croatian Red Cross is the organisation possessing an officein the centre and receives financial contributions from the state, thus having a greater ability to provide a higher level of service. Their mandate is to provide psycho-social assistance and additional material necessities as required, such as clothing and sanitary supplies. Other organisations having their programs in the Kutina centre include: the Croatian Law Centre, Centre for Peace Studies, Jesuit Refugee Service, and Legal Clinic of the Faculty of Law (students' association), some of them being implementing partners of the UNHCR. They are all advocating refugee rights and providing support and assistance in reception centres in a form of free legal aid, Croatian and English language courses, psychosocial counselling, sports activities, creative workshops and others.

Our findings in investigating the Kutina centre indicate that the minimum requirements for reception conditions within reception centres outlined by the EU are being implemented in practice in Croatia. Policy harmonisation reflects the general consensus between the Ministry of the Interior, the UNHCR and the Red Cross who claim that the Croatian asylum legislation seems to be compliant with the EU regulations. In correspondence with the ministry they stated that, "the only challenge is the same as in the EU, which is how to adapt to new migratory flows and the accompanying challenges" (MoI correspondence). An UNHCR respondent expressed a similar opinion in an interview stating that "comparative to other systems in the EU, the current setup within the reception centre in Kutina has been working well" (UNHCR respondent).

However, as emphasized by some NGOs (CPS respondent), language barriers and the lack of social empowerment of asylum seekers within Kutina still undermine their potential adequate integration into Croatian society, possibly due to insufficient minimum standards required by the CEAS and the relative disinterest of the Croatian government for the improvement of such policies. This difficulty of having appropriate harmonised policies was additionally confirmed by the Ministry of the Interior stating that 
"such standards will never be completely equal in all countries since social rights (living standards, minimum wage, health care, etc.) are not the same throughout the whole EU; nor is it possible to achieve an equal level of integration and employment given the different unemployment rates" (MoI correspondence).

According to responses of all stakeholders, general cooperation between the state actors and the various organisations worked well at that time (the start of 2016). However, given that the government officials and civil society representatives were commonly referring to Croatia as a transit country with low numbers of asylum seekers, it seems that the integration policies and longer-term solutions were less relevant and neglected, as most migrants usually desire to solely pass through Croatia. What can be determined from this situation is that the difficulties asylum seekers face when trying to integrate into society indirectly helps the government to maintain the image of Croatia as a transit country, whose initial reception standards are sufficient by the EU standards, but the quality of integration is a rather inefficient, as it was repeatedly concluded by previous studies (Baričević, 2013; Valenta, Zuparic-Iljic and Vidovic, 2015; Jurković, 2018).

\subsection{Service provision and disempowerment within the reception centre}

Asylum seekers' current situation can have dire consequences for their sense of empowerment within the reception capacities, very often characterised by uncertainty of the time spent waiting to become recognised, admitted and feel accepted (Brekke, 2004). Issues such as low levels of privacy, lack of possibilities to work and low financial allowance can all reinforce sentiments of helplessness and hopelessness (Campesi, 2015). As such, what is created is their complete or partial dependency on the reception centre for all the living necessities such as food, clothing and sanitary supplies. This may lead to passivity and decreased chances for implementing proper (pre)integration measures while waiting for the status (Meyer, 2006). Due to the vagueness of the EU legislation, no single unified approach has been defined on how to properly accommodate asylum seekers. With comparatively low numbers of applicants throughout the years, it is questionable why living circumstances in Croatia could not have been ameliorated to improve the reception conditions and integration prospects 
in a way that would encourage socio-psychological empowering and socio-economical emancipation.

Most interviews with asylum seekers demonstrate their dissatisfaction with temporary living conditions. They would prefer private housing if they could afford it. As explained by one of our respondents, an asylumseeking woman who was returned to Croatia under the Dublin Regulation with her family, "we lived in Sweden before and it was much nicer. We had more independence and had our own rooms and a kitchen.". According to an interview with the Red Cross, they are aware that living circumstances are not ideal at Kutina, but claim that they are doing their best, given the situation (Red Cross respondent).

Low financial allowance provided to asylum seekers further disempowers these persons and strengthens their dependency on the centre. Due to the vast contrasts among Member States in the type of services provided and in the amounts of provisions they offer to their own nationals and asylum seekers, it is difficult to make a concrete suggestion of what an appropriate amount of financial allowance should be. As such, the financial allowance provided to asylum seekers in Croatia amounts to less than $20 \%$ of the general welfare given to nationals (around 80 Euro per month). In other words, it comes up to 100 Croatian Kuna (13 Eur) per month for asylum seekers. ${ }^{19}$ As a consequence of being given low allowance, asylum seekers do not have the means to buy certain necessities outside the centre. This makes them fully or partially constrained and oriented on what is being "offered" to them, which might subsequently lead to a dependence mentality and mental health illness (Parker, 2018).

Relying on a third party in order to live creates a sense of helplessness. Such arguments can also be found outside migration literature with scholars such as Dixon and Frolova (2011) analysing the effects of welfare dependency and the negative impact it has on the recipient such as social exclusion and disempowerment. Although at times the distribution does not go as smoothly as it should, with asylum seekers having to wait longer to receive it, they do not ask the MoI to clarify what causes the issue. In the example of one asylum seeker we spoke to, he had not received money for the previous three months and did not know a reason. Responding to our

19 This allowance is low, but is provided solely as pocket money (CPS respondent). The MoI justifies this level of allowance by relating it to general social welfare and economic conditions in Croatia, which are likewise low. In addition, because of the fact that the Croatian Government is covering all the immediate necessities of asylum seekers, such as living and food expenses, there seems to be no will to increase it. 
question as to why he had not asked anyone about the money he stated "I am very grateful for what I have been given, but in my mind, I feel I do not deserve to ask for money. If I had a job, I would feel different about it. For example, I can cut grass and then I know I worked for it and I deserve to be paid".

In fact, most asylum seekers whom we have talked to desire a better life and are willing to work and provide for themselves, which corresponds to the findings among the population of recognised refugees as well, as in the recent research by Ajduković et al. (2019). Being put solely in the receiver position, which is a very passive role, they are stripped off the opportunity to provide for themselves or to have any type of control over their life. This case shows that although all of the basic needs of asylum seekers can be and are being met in Croatia, other types of needs, such as socio-economic emancipation, personal self-actualisation and political and cultural incorporation were seen as of far less importance by the government policies back in 2016. We find that this mind-set discourages proper integration and asylum seekers' potential prosperity within a country, even for those deciding to stay upon obtaining their protection status. However, today, some small advances are reflected first and foremost in the process of preparing local communities for the reception of resettled Syrian refugees, although integration remains a challenging inter-departmental task at different governmental levels, devised from the national framework but also focused on local solutions and practices (Giljević and Lalić Novak, 2018).

\subsection{Language and other barriers}

Language barriers within the reception centre constitute a large obstacle in communication between asylum seekers and the centre's personnel. What we observed is that within the centre, different information is readily available for asylum seekers through either written notice or oral announcements by officials. However, there are still significant communication gaps. This occurs in the form of having difficulties with asking questions and understanding their rights and types of services available to them, a situation which ultimately creates a sense of misunderstanding and a lack of trust. House rules in the Kutina centre are used to explain the rights and obligations of asylum seekers. Additionally, they also highlight other important information, such as: the distribution of clothing, laundry services and information on daily activities. Although such information was read- 
ily available to asylum seekers, it seems as if they were not properly aware of the activities occurring. A group of asylum-seeking women and men who had been there for over a month expressed their concern that a doctor (physician) rarely visited the reception centre and that they had not seen one in weeks. This comes as a contrast to the information provided by a Red Cross representative that a doctor comes twice a week (Red Cross respondent). The doctor does in fact regularly visit the reception centre and some of the asylum seekers we spoke to did not seem to be aware of such services at that time. According to the AIDA report, access to health care is a persistent issue for asylum seekers, especially when it comes to mental health as one of key concerns (Tučkorić, 2019). While downgrading their asylum seekers' psychological and social wellbeing, these shortcomings of the protection system could potentially lead to new adversities, frustrations and vulnerabilities.

When it comes to language classes at the centre, they were offered only once a week for two hours by the JRS and were well attended. These individuals are not professional language instructors, but volunteers interested in providing assistance (JRS respondent). As the Croatian legislation does not require asylum seekers to take language classes until they receive their status, civil society organisations have taken it upon themselves to provide these services to both minor and adult asylum seekers. Most volunteers affiliated with the various organisations present within the reception centre speak either Croatian or English and as a representative from the JRS explains it, “(...) communication is almost always difficult. Even if an asylum seeker understands English, it is questionable how much he actually understands" (JRS volunteer respondent).

The interviews with the CPS and JRS demonstrated that there was a similar issue with language classes being offered outside the centre to refugees who have already obtained their status. Legally, the government is required to provide them, but according to civil society organisations, they were not being organised for a few years due to a lack of financial resources. It was only in 2015 when the classes started owing to the effort from civil society organizations. Government involvement seems to be key in tackling the issues and, if nothing else, should at least allocate the financial scope that could be provided to third parties to plan such classes, as claimed by both the CPS and JRS respondents. Furthermore, recent research by Ajduković et al. (2019) pointed to the fact that a huge majority of stakeholders within the local and regional self-government units in Croatia found that language 
barrier and sufficient language acquisition were the single most important challenge and a prerequisite in the process of refugees' functional integration into society.

The distribution of financing for integration activities is based on the annual program of each Member State and, therefore, funding is indeed available if there is necessity for it. The MoI clarified to us that they allocated $25 \%$ of this EU funds solely to integration purposes (MoI correspondence). With $1 / 4$ of the budget being directed towards such an objective, it is debatable whether a lack of financial capacity can adequately justify the difficulties with providing Croatian language classes, or whether the government's relative disinterest might be at the root of the problem. ${ }^{20}$ Overall, language barriers and the lack of proper and timely information asylum seekers are faced with could greatly impact their sense of empowerment and the possibility of exercising their rights, of using social provisions and services and of preparing for integration. The lack of institutional pressure to adequately incentivise language learning before receiving status is still quite a burden for many of them.

\subsection{Accessibility and movement}

When it comes to the EU minimum requirements for accessibility and mobility i.e. freedom of movement of asylum seekers, the Croatian legislation follows the EU regulations. The reception centre in Kutina is legally considered to be an open facility because asylum seekers have a possibility to leave throughout the day. There are certain limitations to how open the facility truly is, with civilians having to request a special permission to enter the centre and with curfew hours for asylum seekers residing there, which might indirectly discourage their socialisation with Croatian citizens within the premises of the centre. As is common for reception centres in some cases, the centre in Kutina is located on the outskirts of the town, relatively far from residential quarters, which contributes to feelings of marginalisation, exclusion and social isolation in asylum seekers. This location hinders

20 Since Croatia's accession in 2013, the country has also been benefiting from such funding, through which EUR 85.000 were received from the European Refugee Fund until 2016 and in the next 7 years EUR 17.133.800 will be provided by the Asylum, Migration and Integration Fund AMIF (MoI correspondence). This removes a significant burden from the government's budget and helps provide the financial capacity to implement EU policies. As a consequence, what we might ask is if the financial means are only a part of the equation for policy success, with much importance also depending on the political will and awareness within a country to tackle such matters. 
the asylum seekers' sense of belonging with the local community, whose members might to some extent follow the known NIMBY logic (Hubbard, 2005). On the other hand, according to the former mayor of Kutina, "we've always wanted them [asylum seekers] to feel as people and there was always a lot of interest from our side to improve the living conditions and integration within society, but there is a bit of resistance from the Ministry of the Interior, which seems to have other priorities." (Mayor respondent). The mayor also stated that the city of Kutina had offered various ideas, including buying a few computers to be placed in the reception centre which would eventually have decreased the number of people having to walk to the local library in order to use the free Internet service, in a situation where such kind of walk would pose practical difficulties for some of them (the elderly, children). ${ }^{21}$

The freedom of movement for asylum seekers is legally granted within Croatia, and guaranteed in the last version of the International and Temporary Protection Act, with just a few known exceptions (cf. Lalić Novak, Gojević-Zrnić and Radečić, 2014). These policies still contain certain restrictions meaning that the Reception's Centre house rules must be followed or sanctions might be implemented as a consequence. Additionally, if the asylum seeker wishes to leave the facility for a few days, he/she must inform the $\mathrm{MoI}$ and receive a special permit. Such a regulation is in accordance with both the EU and Croatian legislation. According to such rules, asylum seekers must abide by curfew hours, which require them to return to the reception centre by $10 \mathrm{PM}$.

Asylum seekers who are living in isolated and distant reception centres seem to experience a type of unintentional confinement. Bakker, Cheung and Phillimore (2016: 123) who examined a similar living situation in the Netherlands and the UK argue that, "the lack of privacy and autonomy in the Dutch asylum centres can negatively relate to refugees' mental health. Moreover, their dependent position in times of great insecurity can induce passivity and depression". Such living conditions can have a direct impact on the future integration capability of an asylum seeker and create longterm difficulties. The overtly controlled system in Croatia characterised by

21 Nevertheless, there have been a few success stories, with the city of Kutina encouraging the MoI to find financial resources to build a sidewalk and install lights that would connect the reception centre to the city. This construction has somewhat improved the living standard of asylum seekers by increasing their sense of connectivity with the population of Kutina. Moreover, in one period prior to 2015 some of the local NGOs as well as the local social welfare centre provided a mini-van transport for children and families, from the reception centre to main institutions in town and back. 
following a daily regimen and receiving an insufficient monthly allowance creates an effect of a confinement regime where asylum seekers are subject to somewhat restrictive policies that indirectly inhibit their freedom of movement within the local community.

However, having the freedom of movement, disappearance of mostly single male asylum seekers from reception centres occurs on a daily basis, presumably due to leaving the country by utilizing smuggling networks. If they have been gone for more than three days, they are removed from the list of residents in the reception centre as it is assumed that they are not returning. Occasionally, these men are caught crossing the Croatian border into Slovenia and are routinely returned directly to the reception centre without any consequences for violating the house rules. The Red Cross representative within the reception centre explained this situation: "We are not surprised by this at all. Normally the asylum seeker's final destination is not Croatia and their stay here is seen as only a temporary solution. What happens is that they usually either have family in other European countries or believe their life would be better somewhere else, such as Germany or Sweden. These are the main reasons why they try to leave" (Red Cross respondent).

Speaking with two respondents in Zagreb, refugees who have already obtained their asylum status, both explained that many other asylum seekers and grantees have left due to the inability to find a job and integrate properly. The poor economic situation in Croatia can definitely hinder the ability to find employment, but largely it was the inability to speak the language. As one refugee explained it, "I was lucky that I am very good with learning new languages and then with this knowledge I was able to find work translating at the reception centres, but for many of my other friends it was a true struggle". By quickly learning Croatian, both of the refugees had the possibility to integrate more easily. As we see from these examples, the sense of an asylum seeker's temporariness is taken as a given that cannot be improved because they have already determined the desire to leave Croatia, and that is what many of them actually do (cf. Valenta, Zuparic-Iljic and Vidovic, 2015). But this might not apply to all of them, not even maybe to a majority of them, if they had a chance to start a selfdependent life in Croatia. One might repeatedly question if such sense of temporariness is still used as an excuse or justification by the state actors to undermine the necessity of improving the living arrangements for asylum seekers. 


\section{CONCLUDING REMARKS, LESSONS LEARNT AND OPEN QUESTIONS}

Our analysis has shown that although the Croatian legislation is legally in line with the EU Reception Conditions Directive, its practical problems are concerning the adequate provisions of services and integration activities within the reception facilities in Kutina. This is possible due to the fact that the CEAS outlines solely the minimum standards that Member States are required to abide to. As such, it creates policy flexibility that provides state officials with more power over policies and practices being implemented within their respective countries. This legislation can have negative effects on the protection of human rights that the CEAS ostensibly stands for. It is understood by experts that the integration process should ideally start as soon as possible in order to ensure proper adaptation of asylum seekers and to discourage secondary movement to other European countries.

Even if more direct provisions within the Directive of the CEAS could benefit the system, Member States are blocking such a development due to fears of losing sovereignty over policies regarding migration and asylum, and their management. With the slow and gradual progress of Europeanisation, Member States might eventually feel more interconnected with one another, but at this stage, the European project and its sense of unity is still young and state sovereignty is very much present. As long as this is the case, the European integration and the successful development of harmonised policies will not be able to advance to the extent to which it potentially could. Although policy harmonisation can be seen in a positive light when it comes to the case of Croatia, there are still many issues of integration and empowerment of asylum seekers within the reception and integration system. In the case of Croatia, the lack of integration measures in Kutina disables the functional reception and accommodation of asylum seekers and can impact the prospects of future inclusion into Croatian society.

We demonstrated that although the EU's objective was to create an area of a single common asylum policy, and has guided Croatia to gradually develop its asylum laws so as to better reflect EU standards, the ultimate decision on how and where to accommodate asylum seekers still depends on the state's willingness to do so. In comparison to other Member States, Croatia has a relatively low refugee recognition rate and current reception and integration policies have much room for improvement to better reflect the needs of asylum seekers. Currently, services for asylum seekers 
at the Reception Centre Kutina are dependent on the willingness of the Ministry's and Croatian Red Cross personnel, administrative officials, social workers and civil society enthusiasts, the latter ones often lacking the resources to tackle the issue properly. Additionally, the Croatian government has shown moderate disinterest in establishing a coherent, sustainable and more efficient reception and accommodation system, by arguing that in the past, the lack of financial resources had been inhibiting them from providing services even to the claimants who had obtained their status. Consequently, what we see is that the government expresses only a timid interest in a long-term successful integration of asylum seekers and refugees and is able to keep itself at a distance by solely implementing the minimum required by the EU regulations.

What can be determined from this situation is that the difficulties that asylum seekers are facing when to integrating into society help Croatia maintain its image of a transit country. As a consequence, what we see is that Croatia is not taking its share of the burden, which is required by the Reception Conditions Directive in Article 8: "the harmonisation of conditions for the reception of asylum seekers should help to limit the secondary movement of asylum seekers influenced by the variety of conditions for their reception". ${ }^{22}$ Deflecting the issue of proper integration increases secondary movement, which clashes with the EU idea of responsibility sharing and solidarity. On the other hand, newly implemented policies of relocation of asylum seekers from Italy and Greece, and more notably of Syrian refugees from Turkish camps has been just seemingly making a counterbalance in fulfilling these obligations in a humanitarian and solidary manner, whereas by protecting borders and deflecting migrants the state strives to prove itself worthy of entering the Schengen area before the EU technocrats.

We contend that the narrative of Croatia being a transit country is often used by officials (and questioned by scholars) as a self-evidence and excuse for the lack of political will and initiative to provide more and better services to asylum seekers as it is expected that they will not be remaining (longer) in Croatia. Nevertheless, the inconsistencies in the integration policy, such as low chances to learn the language and find employment in the job market (due to low economic conditions), as well as non-existence of social networks of their co-ethnics, constitute reasons for the secondary

22 Directive 2013/33/EU of the European Parliament and of the Council of 26 June 2013 laying down standards for the reception of applicants for international protection, Official Journal of the European Union L 180/96, http://eur-lex.europa.eu/legalcontent/EN/TXT/?uri=celex\%3A32013L0033 
movement of asylum seekers to more promising Western countries. The reasons for the difference in numbers of asylum seekers could vary, but it does match the government's rhetoric that Croatia was, and potentially still is, seen as a transit country where requests for refugee status are low with asylum seekers hoping to start an application in another, more desirable country.

Furthermore, it does not seem that the experience of the Balkan corridor has influenced the reception conditions in the Croatian asylum system significantly besides the opening of the two transit reception centres during the corridor phase (Opatovac and Slavonski Brod). These were established as temporary collective camps for a short-term stay of numerous migrants in transit. Later on, we have seen the establishing of two solid, equipped and closed facilities, i.e. transit reception centres with relatively low capacities (60 beds each) on the very border with Serbia (Tovarnik, opened in fall 2016) and in the Dalmatian region, closer to Bosnia and Herzegovina (Trilj, opened in spring 2017). These are envisaged as detention centres for accelerated asylum procedures and preparations for returns, readmissions and deportations. However, their opening was merely an execution of previously planned arrangements financed from the EU funds within the framework of Croatia's accession to the Schengen.

Today, we are daily witnessing the interception and deflection of irregular migrants on the Balkan route and we are hearing from humanitarian actors about practices of pushbacks taking place on the Croatian, Serbian and Bosnian and Herzegovinian borders. ${ }^{23}$ Therefore, national state policies can be considered inherently restrictive in nature and can impede refugee's rights, namely the right to be admitted to a territory where they may express an intention for protection, as well as to enter a procedure for refugee status recognition. Securitisation practices that are taking place on the Croatian borders are consequently influencing the responses of the borderline local communities in which the government has set up or is planning the adaptation of new reception facilities. At the same time, thousands of irregular migrants being stranded under inhumane living conditions in two Bosnian towns (Bihać and Velika Kladuša) remind us once more of the inefficacy of EU policies to tackle and resolve this special humanitarian

23 For troublesome practices of violence towards migrants on borders see: www.hrw.org/ news/2017/01/20/croatia-asylum-seekers-forced-back-serbia; www.ecre.org/op-ed-asylum-seekers-in-croatia-in-a-human-rights-vacuum/; www.hrw.org/news/2018/12/11/croatia-migrantspushed-back-bosnia-and-herzegovina 
concern in regard to the reception and protection of people in need. ${ }^{24}$

It seems that today, when the corridor ceased to exist, the Croatian Government has to envisage establishing more facilities for the reception and accommodation of increased numbers of people approaching Croatian borders, as those who eventually might express their intention for a protection status. On the other hand, some individual stories of Syrian refugees recently resettled from Turkish camps to local communities across Croatia have brought to light the issues of reception, adaptation and longer-term integration. One could legitimately ask when and if the public interest diverged from appraising the Croatian Government's new form of "opportunistic humanitarianism" while keeping the security of borders intact, even at the expense of the oftentimes irregularised and criminalised human lives of migrants.

However, nowadays an important task relates to working with citizens from local communities in order to inform and sensitise them to the presence, rights and duties of their new neighbours, mostly families of Syrian refugees. At least in one place, this sensitisation is a rather onerous endeavour concerning negative sentiments of the local public towards the Government's plan to adapt a new facility for the reception of asylum seekers in their small community. The Croatian Government plans to build a new Reception Centre for asylum seekers in the small village of Mala Gorica, which is approximately 50 kilometres distant from Velika Kladuša, where many migrants try to enter the Croatian territory. In July 2018, the Ministry of the Interior's Independent Sector for Schengen Coordination and EU Funds decided to allocate funds to the project of "Establishing Infrastructure and Capacity Building of the Reception Centre for Asylum Seekers in Mala Gorica within the Asylum, Migration and Integration Fund", not without revolt and obstruction from the local authorities, and resistance of local citizens. ${ }^{25} \mathrm{~A}$ challenging time is ahead for the state asylum system, local communities and Croatian society, with many of unanswered questions on future standards of reception, accommodation and integration of the asylum seeking and refugee population in Croatia.

24 See: https://reliefweb.int/report/bosnia-and-herzegovina/migrants-near-bosnian-croatian-border-ill-equipped-survive-freezing and https://www.politico.eu/article/bosnias-migrant-routebottleneck/

25 See: http://hr.n1info.com/English/NEWS/a367346/Petrinja-town-council-decides-not-to-allowbuilding-of-migrant-shelter-near-town.html 


\section{REFERENCES}

Ajduković, D., Čorkalo Biruški, D., Gregurović, M., Matić Bojić, J. and Župarić-Iljić, D. (2019). Challenges of Integrating Refugees into Croatian Society: Attitudes of Citizens and the Readiness of Local Communities. Zagreb: Government of the Republic of Croatia Office for Human Rights and Rights of National Minorities.

Bačić Selanec, N. (2015). A Critique of EU Refugee Crisis Management: On Law, Policy and Decentralisation, Croatian Yearbook of European Law E Policy, 11 (11): 73-114, doi: https://doi.org/10.3935/cyelp.11.2015.230

Bakker, L., Cheung, S. Y. and Phillimore, J. (2016). The asylum-integration paradox: comparing asylum support systems and refugee integration in the Netherlands and the UK, International Migration, 54 (4): 118-131, doi: https://doi.org/10.1111/ imig. 12251

Barberić, J. (2015). Asylum in the Republic of Croatia One Year After Accession to the European Union. Oxford: University of Oxford - UNHCR (New Issues in Refugee Research, Research Paper No. 273), http://www.unhcr.org/research/working/54dca6ee9/ asylum-republic-croatia-year-accession-european-union-jasna-barberi.html (15 February 2019).

Baričević, V. 2013. Europeanization of Asylum System and Refugee Protection: Croatian Asylum and Migration Policies (Unpublished PhD thesis). Ljubljana: University of Ljubljana, Faculty of Social Sciences.

Belgrade Centre for Human Rights (BCHR) (2015). Right to Asylum in the Republic of Serbia 2014. Belgrade.

Brekke, J. (2004). While We Are Waiting: Uncertainty and Empowerment Among AsylumSeekers in Sweden. Oslo: Institute for Social Research.

Bužinkić, E. and Hameršak, M. (eds) (2018). Formation and Disintegration of the Balkan Refugee Corridor: Camps, Routes and Borders in Croatian Context. Zagreb - München: Institute of Ethnology and Folklore Research - Centre for Peace Studies - Faculty of Political Science - bordermonitoring.eu e.V.

Campesi G. (2015). Humanitarian confinement: an ethnography of reception centres for asylum seekers at Europe's southern border, International Journal of Migration and Border Studies, 1 (4): 398-418, doi: https://doi.org/10.1504/ijmbs.2015.070785

Chetail, V. (2016). Looking beyond the Rhetoric of the Refugee Crisis: The Failed Reform of the Common European Asylum System, European Journal of Human Rights, 5: 584602.

Costello, C. and Hancox, E. (2015). The Recast Asylum Procedures Directive 2013/32/EU: Caught between the Stereotypes of the Abusive Asylum Seeker and the Vulnerable Refugee. Oxford: University of Oxford (Oxford Legal Studies Research Paper No. 33/2015).

Dixon, J. and Frolova, Y. (2011). Existential Poverty: Welfare Dependency, Learned Helplessness and Psychological Capital, Poverty and Public Policy, 3 (2): 279-298, doi: https://doi.org/10.2202/1944-2858.1158 
European Council on Refugees and Exiles (ECRE) (2016). ECRE Comments on the Commission Proposal to recast the Reception Conditions Directive COM(2016) 465, October 2016, https://www.ecre.org/wp-content/uploads/2016/10/ECRE-CommentsRCD.pdf

ECRE and AIDA (2016). Balkan Route Reversed: The Return of Asylum Seekers to Croatia Under the Dublin System. Brussels: European Council on Refugees and Exiles Asylum Information Database, www.asylumineurope.org/sites/default/files/ resources/balkan_route_reversed.pdf

European Commission (2005). Croatia 2005 Progress Report, COM (2005) 561 final. Brussels.

European Commission (2010). Croatia 2010 Progress Report accompanying the Communication from the Commission to the European Parliament and the Council. Enlargement Strategy and Main Challenges 2010-2011, COM (2010) 660. Brussels.

European Commission (2016). The EU and the Refugee Crisis. http://publications.europa. eu/webpub/com/factsheets/refugee-crisis/en/

Giuffré, M. (2013). Readmission Agreements and Refugee Rights: From a Critique to a Proposal, Refugee Survey Quarterly, 32 (3): 79-111, doi: https://doi.org/10.1093/rsq/ hdt012

Giljević, T. and Lalić Novak, G. (2018). Coordination Instruments in Croatian Integration Policy: Classification, Evaluation, and Proposals for Improvements, Hrvatska i komparationa javna uprava, 18 (3), 373-396, doi: https://doi.org/10.31297/hkju.18.3.1

Guest, G., MacQueen, K. M. and Namey, E. E. (2012). Applied Thematic Analysis. Thousand Oaks: Sage Publications, doi: https://doi.org/10.4135/9781483384436

Hameršak, M. and Pleše, I. (2017). Winter Reception and Transit Center in the Republic of Croatia: An Ethnographic View of the Slavonski Brod Refugee Camp, Narodna umjetnost, 54 (1): 101-127, doi: https://doi.org/10.15176/vol54no106

Hameršak, M. and Pleše, I. (2018). Confined in Movement: The Croatian Section of the Balkan Corridor, in: E. Bužinkić and M. Hameršak (eds). Formation and Disintegration of the Balkan Refugee Corridor: Camps, Routes and Borders in Croatian Context. Zagreb München: Institute of Ethnology and Folklore Research - Centre for Peace Studies - Faculty of Political Science - bordermonitoring.eu e.V., 9-41.

Hubbard, P. (2005). Accommodating Otherness: Anti-Asylum Centre Protest and the Maintenance of White Privilege, Transactions of the Institute of British Geographers, 30 (1): 52-65, doi: https://doi.org/10.1111/j.1475-5661.2005.00151.x

Jurković, R. (2018). The Integration of Refugees into Croatian Society. Ethnographies of Exercising Rights, Etnološka tribina, 48 (41), 102-121, doi: https://doi.org/10.15378/18489540.2018.41.02

Kasparek, B. and Speer, M. (2015). Of hope. Hungary and the long summer of migration. Boredrmonitoring.eu, February 9, 2015, http://bordermonitoring.eu/ungarn/2015/09/ of-hope-en/ (15 February 2019). 
Lalić Novak, G. and Padjen, I. (2009). The Europeanization of Asylum Policy: From Sovereignty via Harmony to Unity, Politička misao, 46 (5): 75-101.

Lalić Novak, G., Gojević-Zrnić, M. and Radečić, G. (2014). Alternative ograničavanju slobode kretanja tražitelja azila u Republici Hrvatskoj - analiza stanja, komparativni pregled i preporuke de lege ferenda, Zbornik radova Pravnog fakulteta u Splitu, 51, (1): 85-99.

Lalić Novak, G. (2016). Azil: pravni i institucionalni aspekti. Zagreb: Pravni fakultet Sveučilišta u Zagrebu.

Lindstrom, C. (2005). European Union Policy on Asylum and Immigration. Addressing the Root Causes of Forced Migration: A Justice and Home Affairs Policy of Freedom, Security and Justice?, Social Policy \& Administration, 39 (6): 587-605, doi: https://doi. org/10.1111/j.1467-9515.2005.00458.x

Meyer, S. (2006). The 'refugee aid and development' approach in Uganda: empowerment and self-reliance of refugees in practice. Oxford: University of Oxford - UNHCR (New Issues in Refugee Research, Research Paper No. 131).

Mikac, R. and Cesarec, I. (2017). The Balkans and Refugee Crisis: Lessons Identified and way forward, Security Dialogues, 8 (2): 169-188.

OXFAM, BCHR and MYLA (2017). A Dangerous 'Game': The Pushback of Migrants, Including Refugees, at Europe's Borders. Joint Agency Briefing Paper, April 2017. Oxfam, Belgrade Centre for Human Rights, and Macedonian Young Lawyers Association. https://www.oxfam.org/sites/www.oxfam.org/files/file_attachments/bp-dangerousgame-pushback-migrants-refugees-060417-en_0.pdf

Pandek, K. (2017). The Provision of Services to Asylum Seekers in Croatia's Reception Centre Kutina (Master of Arts Thesis in European, Russian and Eurasian Studies). Ottawa: Carleton University, Faculty of Graduate and Postdoctoral Affairs.

Parker, S. (2018). 'Just eating and sleeping': asylum seekers' constructions of belonging within a restrictive policy environment, Critical Discourse Studies, doi: https://doi.org /10.1080/17405904.2018.1546198

Pirjola, J. (2009). European Asylum Policy - Inclusions and Exclusions under the Surface of Universal Human Rights and Language, European Journal of Migration and Law, 11 (4): 347-366, doi: https://doi.org/10.1163/138836409x12501577630669

Pastore, F. (2019). From Source to Corridor: Changing Geopolitical Narratives about Migration and EU-Western Balkans Relations, Journal of Balkan and Near Eastern Studies, 21 (1): 11-26, doi: https://doi.org/10.1080/19448953.2018.1532683

Pollet, K., Soupios-David, H. and Teffera, A. (2013). Not There Yet: An NGO Perspective on Challenges to a Fair and Effective Common European Asylum System. Brussels: ECRE - AIDA, http://www.asylumineurope.org/sites/default/files/shadow-reports/not_ there_yet_02102013.pdf (15 February 2019).

Pozniak, R. and Petrović, D. (2014). Tražitelji azila kao prijetnja, Studia ethnologica Croatica, 26 (1): 47-72, doi: https://doi.org/10.17234/sec.26.3 
Rogelj, B. (2017). The Changing Spatiality of the "European Refugee/Migrant Crisis", Migracijske i etničke teme, 33 (2): 191-219, doi: https://doi.org/10.11567/ met.33.2.4

Sardelić, J. (2017). From Temporary Protection to Transit Migration: Responses to Refugee Crises along the Western Balkan Route. Florence: European University Institute (Robert Schuman Centre for Advanced Studies Research Paper No. RSCAS 2017/35).

Schweitzer, R., Consterdine, E. and Collyer, M. (2018) A review and analysis of the recent literature on the Common European Asylum System. Chemnitz: Technische Universität Chemnitz, Institut für Europäische Studien (CEASEVAL, Research on the Common European Asylum System Nr. 03).

Squire, V. (2009). The Exclusionary Politics of Asylum. London - New York: Palgrave Macmillan, doi: https://doi.org/10.1057/9780230233614

Šelo Šabić, S. (2017). The Impact of the Refugee Crisis in the Balkans: A Drift Towards Security, Journal of Regional Security, 12 (1): 51-74, doi: https://doi.org/10.11643/ issn.2217-995x171sps80

Triandafyllidou, A. and Dimitriadi A. (2014). Deterrence and Protection in the EU's Migration Policy, The International Spectator, 49 (4): 146-162, doi: https://doi.org/10.1 080/03932729.2014.956280

Tučkorić, L. (2019). Country Report: Croatia (2018 Update). AIDA: Asylum Information Database. https://www.asylumineurope.org/sites/default/files/report-download/ aida_hr_2018update.pdf (15 February 2019).

Valenta, M., Zuparic-Iljic, D. and Vidović, T. (2015). The Reluctant Asylum-Seekers: Migrants at the Southeastern Frontiers of the European Migration System, Refugee Survey Quarterly, 34 (3): 95-113, doi: https://doi.org/10.1093/rsq/hdv009

Van Moortel, G. (2007). UNHCR study finds inconsistency in EU on asylum, unhcr.org, November 6, 2007, http://www.unhcr.org/news/latest/2007/11/4730a0512/unhcrstudy-finds-inconsistency-euasylum.html?query=CEAS (15 February 2019).

Velluti, S. (2014). CEAS, Asylum-Seekers and EU Human Rights Post-Lisbon: Closing the Gaps in the European Protection Regime, in: S. Velluti (ed.). Reforming the Common European Asylum System-Legislative Developments and Judicial Activism of the European Court. Lincoln: Springer, 105-110, doi: https://doi.org/10.1007/978-3-642-40267-8_5 


\title{
Jačanje granica, upravljanje prihvatilištima: uvjeti prihvata i pružanje usluga tražiteljima azila u Hrvatskoj
}

\author{
Kristina Pandek, Drago Župarić-Iljić
}

\begin{abstract}
SAŽETAK
Ovaj članak analizira utjecaj koji Zajednički europski sustav azila može imati na tražitelje azila koji borave u prihvatnim centrima u Hrvatskoj kao i novije izazove povezane s povećanjem broja tražitelja azila i poteškoćama koje bi to moglo predstavljati u odnosu na standarde prihvata i pružanje usluga. Autori tvrde da je prisutan određeni stupanj razlikovanja u tretmanu tražitelja azila u prihvatnim centrima unutar EU-a. Ova analiza stavlja naglasak na sustav azila u Hrvatskoj kao onaj koji je tijekom procesa pristupanja EU-u bio zakonski obvezan u potpunosti uskladiti svoje politike s pravnom stečevinom EU-a. Na temelju terenskog istraživanja metodom polustrukturiranih intervjua među dionicima sustava azila i tražiteljima azila u Prihvatilištu za tražitelje azila Kutina u 2016., rezultati upućuju na to da iako je Hrvatska u potpunosti prilagodila svoju regulativu Direktivi o uvjetima prihvata, još uvijek postoje izazovi koji se odnose na minimalne standarde kvalitete prihvata, pružanja usluga i buduće integracije tražitelja zaštite. Tvrdi se da raskorak i nedostaci u uvjetima i standardima prihvata izravno smanjuju izglede tražitelja azila, utječući na njihove mogućnosti integracije u hrvatsko društvo, što također rezultira značajnim sekundarnim kretanjima tih migranata u druge zemlje EU-a. Štoviše, nakon Balkanskoga koridora, današnji izazovi povećanog broja tražitelja azila pozivaju na planiranje novih i prikladnih prihvatnih objekata, što je u kontekstu otvorene sekuritizirane politike azila i migracija teže ostvariv zadatak.
\end{abstract}

KLJUČNE RIJEČI: tražitelji azila, Zajednički europski sustav azila (CEAS), prihvat, Hrvatska, Balkanski koridor, izbjeglice, integracija 